\title{
Analisis Kemampuan Penalaran dan Komunikasi Matematis Siswa
}

\author{
Sefna Rismen' ${ }^{\text {, Ainil Mardiyah }}{ }^{2}$, dan Ega M Puspita ${ }^{3}$ \\ Pendidikan Matematika, STKIP PGRI Sumatera Barat \\ Gunung Pangilun, Padang, Sumatera Barat, Indonesia \\ 1syefna@gmail.com,2m.ainil@yahoo.com,3egameilia97@gmail.com
}

Artikel diterima: 30-10-2019, direvisi: 28-05-2020, diterbitkan: 31-05-2020

\begin{abstract}
Abstrak
Latar belakang penelitian adalah rendahnya kemampuan penalaran dan komunikasi matematis siswa. Penelitian ini bertujuan untuk mengetahui bagaimana kemampuan penalaran dan komunikasi matematis siswa kelas XI MIA (Matematika dan IImu Alam) SMAN 1 Koto Salak Kabupaten Dharmasraya. Metode penelitian adalah penelitian deskriptif dengan pendekatan kualitatif. Instrumen yang digunakan berupa tes, wawancara, dan observasi. Subjek penelitian adalah siswa kelas XI MIA SMAN 1 Koto Salak sebanyak 27 orang. Hasil penelitian menunjukkan kriteria kemampuan penalaran dan komunikasi matematis siswa sangat baik sebanyak 3 orang, baik sebanyak 6 orang, cukup sebanyak 7 orang, kurang sebanyak 9 orang, dan sangat kurang sebanyak 2 orang. Jadi, dapat disimpulkan bahwa kemampuan penalaran dan komunikasi matematis siswa kelas XI MIA SMAN 1 Koto Salak dominan berada pada kriteria kurang baik.

Kata Kunci: kemampuan penalaran matematis, komunikasi matematis matematis, penelitian deskriptif, kualitatif.
\end{abstract}

\section{Analysis of Students' Mathematical Reasoning and Communication Capabilities}

\begin{abstract}
The background of the research is the low mathematical reasoning and communication skills of students. This study aims to assess the mathematical reasoning and communication skills of students of class XI in the Science program of Senior High School No 1 (SMAN 1) in Koto Salak, Dharmasraya Regency. The research method used was a descriptive study with a qualitative approach while the instruments used are in the form of tests, interviews, and observations, with 27 students as the research subjects. The results showed that the criteria of students'mathematical reasoning and communication skills as follows; very good as many as 3 people, good as many as 6 people, fairly good as many as 7 people, bad as many as 9 people, and very bad as many as 2 people. Therefore, it can be concluded that the mathematical reasoning and communication skills of students in class XI in the Science Program of Senior High School No. 1 Koto Salak are in poor criteria.

Keywords: mathematical reasoning skills, mathematical communication skills, descriptive research, qualitative.
\end{abstract}




\section{Pendahuluan}

Matematika merupakan suatu ilmu yang didasarkan atas akal (rasio) yang berhubungan benda-benda dalam pikiran yang abstrak atau matematika memiliki objek kajian yang abstrak (Soedjadi, 2000). Tujuan matematika yaitu dapat menciptakan kemampuan intelektual, mampudalam menyelesaikan masalah, melatih mengkomunikasikan ide-ide, serta dapat mengembangkan karakter siswa. Oleh karena itu, maka salah satu tujuan matematika yang harus dikuasai siswa adalah kemampuan penalaran dan komunikasi.

Penalaran adalah pemikiran yang diadopsi untuk menghasilkan pernyataan dan mencapai kesimpulan pada pemecahan masalah yang tidak selalu didasarkan pada logika formal sehingga tidak terbatas pada bukti (Khoirudin \& Rizkianto, 2018; Utomo, Rahman, \& Fikrati, 2020), sedangkan komunikasi adalah aktivitas kelas yang menawarkan kemungkinan bagi siswa untuk mengembangkan pemahaman yang lebih dalam tentang matematika yang mereka pelajari (Rosita, 2008). Jadi, kemampuan penalaran dan komunikasi siswa yang baik sangat penting karena melalui komunikasi akan terlihat sejauh mana siswa mengeksplorasi pemikiran dan pemahaman mereka terhadap pembelajaran matematika (Rosita, 2008; Dewi \& Afriansyah, 2018; Luritawaty, 2019). Sehingga semakin tinggi tingkat penalaran siswa, maka akan mempercepat proses pembelajaran guna mencapai indikator-indikator pembelajaran (Inayah, 2016).

Indikator penalaran dan komunikasi matematis dalam Shadiq (2009) yaitu 1). Menyajikan pernyataan matematika secara lisan, tertulis, gambar dan diagram. 2). Mengajukan dugaan. 3). Melakukan manipulasi matematika. 4). Menarik kesiimpulan, menyususn bukti, memberikan alasan atau bukti terhadap beberapa solusi. 5). Menarik kesimpulan dari pernyataan. 6). Memeriksa kesahihan suatu argumen. 7). Menemukan pola atau sifat dari gejala matematika untuk membuat generalisasi.

SMAN 1 Koto Salak adalah salah satu sekolah negeri di Kabupaten Dharmasraya. Hasil belajar matematika siswa di sekolah ini tergolong masih rendah. Hal ini dilihat dari persentase ketuntasan belajar siswa pada materi Vektor yaitu 10,53 \%. Hasil pengamatan saat proses pembelajaran matematika terlihat bahwa siswa belum mampu menyelesaikan soal yang berbeda dengan contoh yang diberikan guru.

Hasil penelitian terdahulu oleh (Inayah, 2016) menunjukkan bahwa kemampuan penalaran sangat diperlukan untuk mencapai hasil belajar matematika dengan baik. Peningkatan kemampuan bernalar peserta didik selama proses pembelajaran sangat diperlukan guna mencapai keberhasilan. Komunikasi merupakan salah satu keterampilan proses, yaitu berkaitan dengan kemampuan siswa dalam menyampaikan atau menerima 
gagasan/ide agar lebih kreati, baik melalui lisan maupun tulisan (Agisti, 2009; Asmara \& Afriansyah, 2018). Jadi, pentingnya kemampuan penalaran dan komunikasi matematis menjadikan peneliti ingin mengadakan penelitian dengan tujuan untuk mengetahui bagaimana kemampuan penalaran dan komunikasi matematis siswa kelas XI MIA SMAN 1 Koto Salak Kabupaten Dharmasraya.

\section{Metode}

Jenis penelitian ini adalah penelitian deskriptif dengan pendekatan kualitatif. Instrumen yang digunakan adalah tes yang diberikan dalam bentuk uraian (essay), wawancara, dan observasi (Afriansyah, 2013). Tes yang digunakan memiliki reliabelitas yaitu $r_{11}=0,87$ dan $r_{\text {tabel }}=$ 0,468, karena $r_{11}>r_{\text {tabel }}$ dapat disimpulkan bahwa soal dinyatakan reliabel. Teknik pengumpulan data yaitu dimulai dari tahap persiapan (membuat kisi-kisi soal tes, menyusun soal tes dan kunci jawaban kisi-kisi soal tes, menyusun soal tes dan kunci jawaban, memvalidasikannya kepada pakar pendidikan matematika dan praktisi/guru), menyusun instrumen wawancara, mengambil data ulangan harian siswa dan mengelompokkan berdasarkan kriteria kemampuan awal matematis), tahap pelaksanaan (memberikan soal tes, dan melakukan wawancara), hingga tahap akhir (mengolah dan menganalisa data yang telah diperoleh dari jawaban tes tertulis dan wawancara menggunakan analisa deskriptif kualitatif). Teknik analisis data yang digunakan skala 100, dengan rumus:

Skor yang diperoleh $=$ bobot $\times$ skala Nilai Siswa $=\frac{\text { jumlah skor yang diperoleh siswa }}{\text { jumlah skor total }} \times 100$ Setelah itu, dilakukan pengelompokkan berdasarkan kriteria sebagai berikut:

Tabel 1.

Kriteria Hasil Tes Kemampuan Penalaran dan Komunikasi Matematis Siswa

\begin{tabular}{cc|}
\hline Kriteria & Nilai \\
\hline Sangat Baik & $80 \leq N \leq 100$ \\
\hline Baik & $60 \leq N<80$ \\
\hline Cukup & $40 \leq N<60$ \\
\hline Kurang & $20 \leq N<40$ \\
\hline Sangat Kurang & $0 \leq N<20$
\end{tabular}

Sumber: Modifikasi (Emilya, n.d.,2010)

Keterangan:

$N=$ Nilai tes kemampuan penalaran dan komunikasi matematis siswa

Setelah dilakukan tes kemudian dilakukan wawancara, hasil wawancara dianalisis dengan metode deskriptif kualitatif. Subjek penelitian yaitu siswa kelas XI MIA (Matematika dan IImu Alam) SMAN 1 Koto Salak yang berjumlah 27 orang.

\section{Hasil dan Pembahasan}

Hasil tes kemampuan penalaran dan komunikasi matematis subjek penelitian yang terdiri dari 27 orang sebagai berikut:

Tabel 2.

Hasil Kemampuan Penalaran dan Komunikasi Matematis Siswa

\begin{tabular}{clc}
\hline No & $\begin{array}{c}\text { Kemampuan Penalaran dan } \\
\text { Komunikasi Matematis Siswa }\end{array}$ & Jumlah \\
\hline 1 & Sangat Baik & 3 \\
\hline 2 & Baik & 6 \\
\hline 3 & Cukup & 7 \\
\hline
\end{tabular}




\begin{tabular}{|rlc|}
\hline 4 & Kurang & 9 \\
\hline 5 & Sangat Kurang & 2 \\
\hline & Jumlah & 27 \\
\hline
\end{tabular}

Berdasarkan Tabel 2 terlihat bahwa kriteria kemampuan penalaran dan komunikasi matematis siswa adalah dominan kurang baik. Artinya kemampuan penalaran dan komunikasi matematis harus ditingkatkan lagi. Kemampuan penalaran dan komunikasi matematis siswa dilihat dari kemampuan awal matematisnya dapat dilihat pada tabel berikut:

Tabel 3.

Hasil Kemampuan Awal Matematis Siswa (KAM) dan Kemampuan Penalaran dan Komunikasi

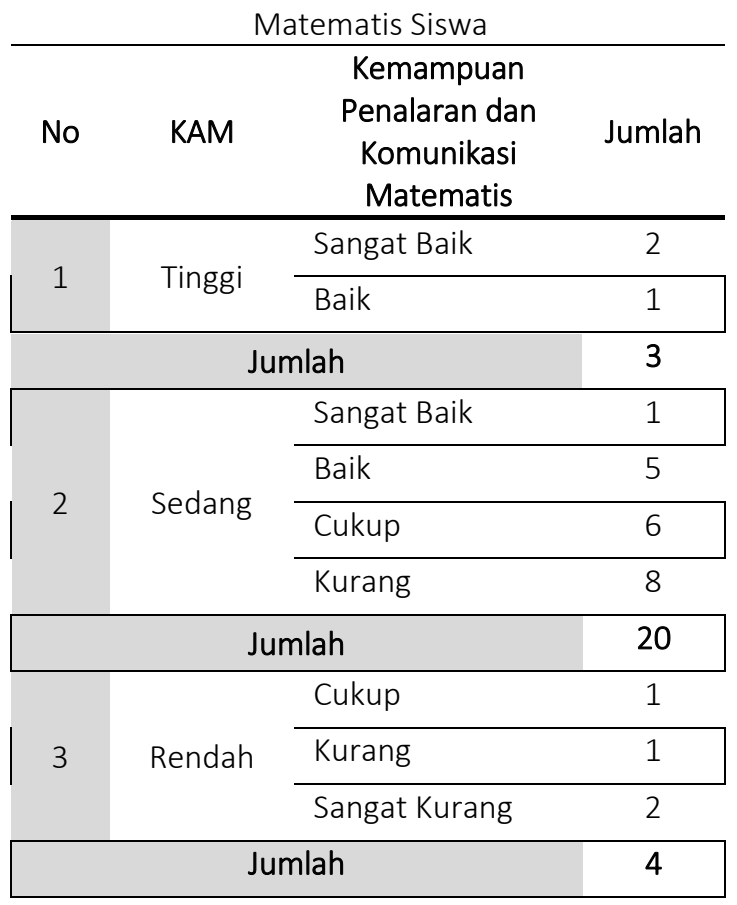

Berdasarkan Tabel 3 terlihat bahwa siswa yang memiliki kemampuan awal matematis tinggi memiliki kriteria kemampuan penalaran matematis yang dominan sangat baik. Siswa yang memiliki kemampuan awal matematis sedang yaitu dominan kurang baik. Sedangkan siswa yang memiliki kemampuan awal matematis rendah yaitu dominan Sangat Kurang. Artinya kemampuan awal matematis tidak menyebabkan kriteria kemampuan penalaran dan komunikasinya sama.

Kemampuan penalaran dan komunikasi matematis yang dilihat dari hasil tes, dimana soal tes disusun berdasarkan indikator kemampuan penalaran dan komunikasi matematis. Hasil analisis indikator kemampuan penalaran dan komunikasi matematis yang diambil 1 orang dari masing-masing kriterianya yang dianalisis setiap indikator, yang dapat dilihat sebagai berikut:

Tabel 4.

Analisis Indikator Kemampuan Penalaran dan Komunikasi Matematis Siswa

\begin{tabular}{|ccccccc|}
\hline & Kemampuan & \multicolumn{5}{c}{ Indikator } \\
\cline { 3 - 7 } Kode & $\begin{array}{c}\text { Penalaran } \\
\text { dan }\end{array}$ & 1.1 & 1.2 & 1.3 & 1.4 & 1.5 \\
\cline { 3 - 7 } & $\begin{array}{c}\text { Komunikasi } \\
\text { Matematis }\end{array}$ & 6 & 6 & 24 & 6 & 9 \\
\hline RH & Sangat Baik & 4 & 6 & 24 & 5 & 8 \\
\hline AP & Baik & 4 & 6 & 20 & 1 & 9 \\
\hline NA & Cukup Baik & 2 & 6 & 13 & 1 & 1 \\
\hline FD & Kurang Baik & 4 & 2 & 6 & 2 & 1 \\
\hline CM & $\begin{array}{l}\text { Sangat } \\
\text { Kurang }\end{array}$ & 2 & 0 & 0 & 2 & 0 \\
\hline
\end{tabular}

Keterangan: Indikator kemampuan penalaran dan komunikasi siswa:

1.1 Menyajikan pernyataan mateatika secara tertulis, gambar, dan diagram.

1.2 Mengajukan dugaan melalui pemilihan rumus atau defenisi

1.3 Melakukan manipulasi matematika melalui perhitungan

1.4 Menarik kesimpulan dari pernyataan

1.5 Menarik kesimpulan, menyusun bukti, memberikan alasan atau bukti terhadap beberapa solusi. 
Berdasarkan Tabel 4 diperoleh bahwa ketercapaian masing-masing siswa pada setiap indikator mempunyai keberagaman. Pada siswa yang memiliki kemampuan penalaran dan komunikasi matematis sangat baik memiliki ketercapaian maksimal pada indikator mengajukan dugaaan melalui pemilihan rumus atau defenisidan indikator melakukan manipulasi matematika melalui perhitungan. Pada siswa yang memiliki kemampuan penalaran dan komunikasi matematis baik dan cukup baik memiliki ketercapaian maksimal pada indikator mengajukan dugaaan melalui pemilihan rumus. Sedangkan siswa yang memiliki kemampuan penalaran dan komunikasi matematis kurang baik dan sangat kurang tidak memiliki ketercapaian maksimal dari kelima indikator tersebut.

Berikut ini bentuk jawaban siswayang dianalisis berdasarkan indikator kemampuan penalaran dan komunikasi matematis yang mana satu kriteria mewakili setiap indikator:

1. Menyajikan Pernyataan Matematika Secara Tertulis, Gambar, Dan Diagram.

Soal nomor 1A: Tentukan himpunan penyelesaian dari $\sin x=0$ untuk $0^{\circ} \leq$ $x \leq 2 \pi$, dengan menggunakan cara grafik fungsi trigonometri

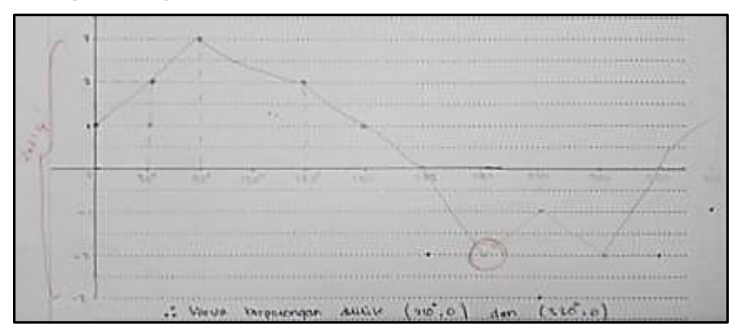

Gambar 1. Lembar Jawaban Siswa Kriteria Sangat Baik
Berdasarkan gambar tersebut, terlihat bahwa siswa berada pada skala 2, dikarenakan ada sedikit kekurangan yaitu dalam membuat skala dan kerapian menghubungkan titik koordinat ke titik koordinat lainnya. Berdasarkan hasil wawancara siswa mengatakan kesulitan dalam menentukan titik koordinat pada sumbu $Y$ dikarenakan nilai sin memuat akar-akar yaitu $\sqrt{2}$ dan $\sqrt{3}$. Jadi, siswa mengalami kendala dalam menentukan letak titik koordinat pada sumbu Y.

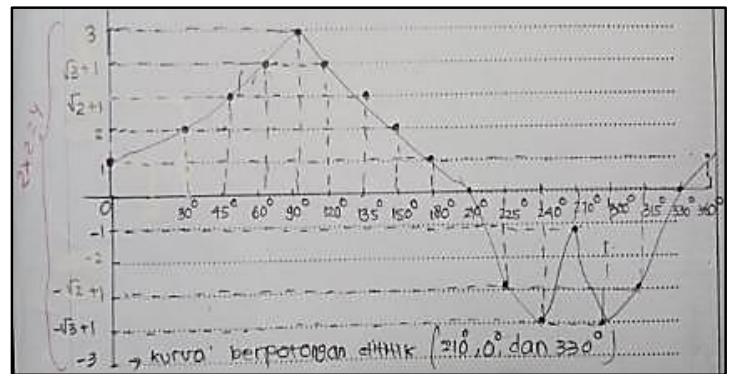

Gambar 2. Lembar Jawaban Siswa Kriteria Baik

Terlihat bahwa siswa berada pada skala 2, dikarenakan ada kekurangan dalam membuat skala dan menentukan titik koordinat dari sudut $225^{\circ}, 240^{\circ}, 300^{\circ}$. $315^{\circ}$. Berdasarkan hasil wawancara yang dilakukan, siswa mengalami kesulitan dan merasa jawaban yang dibuat salah dikarenakan siswa tidak tahu nilai $\sqrt{2} \operatorname{dan} \sqrt{3}$ itu berapa, dan siswa mengatakan bahwa bentuk grafik yang dibuat tidak konsisten. Jadi, siswa mengalami kendala pada nilai akar namun bentuk grafik yang dibuat juga kurang tepat dalam menentukan titik koordinat. 


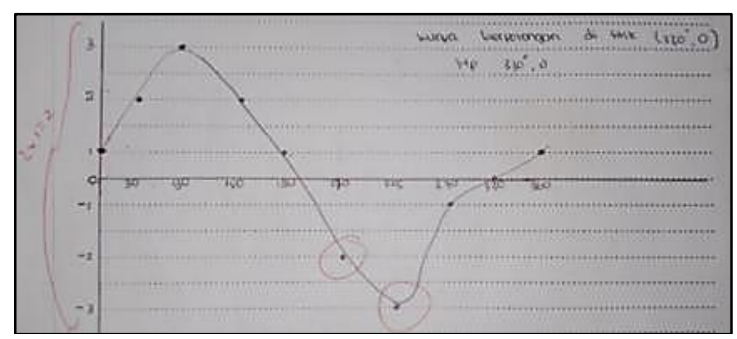

Gambar 3. Lembar Jawaban Siswa Kriteria Cukup Baik

Dapat dilihat bahwa siswa berada pada skala 1, dikarenakan jawaban siswa tidak jelas dalam menentukan titik-titik koordinat dan ada kesalahan dalam menentukan titik tersebut, dan siswa juga tidak menggambar dengan skala yang sama. Berdasarkan hasil wawancara siswa mengatakan bahwa mengalami kesulitan menuangkan dari bentuk tabel ke bentuk grafik. Jadi, siswa belum mampu membuat penyataan matematika karena terdapat kesalahan dan kurang jelas dalam menentukan titik koordinat.

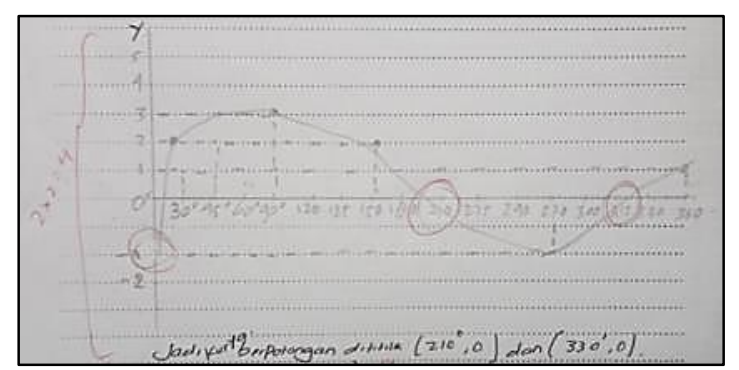

Gambar 4. Lembar Jawaban Siswa Kriteria Kurang Baik

Pada gambar tersebut siswa berada pada skala 2, dikarenakanada kekurangan yaitu dalam membuat skala dan menentukan titik koordinat pada sudut $0^{\circ}, 210^{\circ}, 315^{\circ}$. Berdasarkan hasil wawancara siswa mengatakan mengalami kesulitan dan kendala dalam menentukan letak titik koordinat. Jadi, siswa belum mampu membuat penyataan matematika secara tertulis maupun membuat grafik.

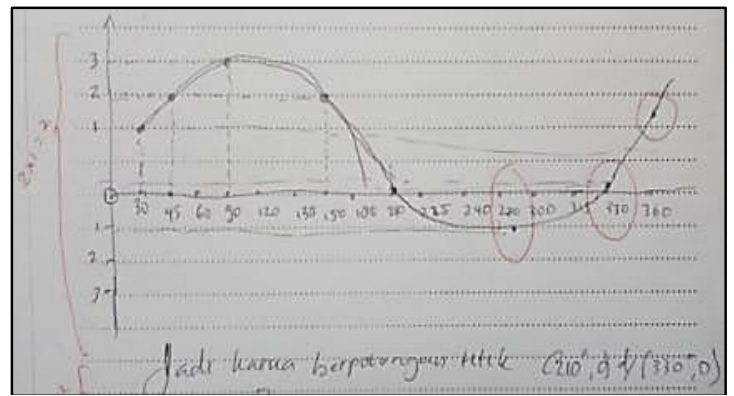

Gambar 5. Lembar Jawaban Siswa Kriteria Sangat Kurang

Terlihat bahwa siswa berada pada skala 1, hal ini dikarenakan ada kesalahan siswa dalam menentukan letak titik koordinat $30^{\circ}=1$ yang seharusnya $30^{\circ}=$ 2 , titik koordinat $270^{\circ}, 330^{\circ}$, dan $360^{\circ}$ tidak jelas dan tidak tepat yang dibuat oleh siswa, yang seharusnya titik koordinat $270^{\circ}=-1,330^{\circ}=0, \quad$ dan $360^{\circ}=$ 1.Berdasarkan hasil wawancara siswa mengatakan mengalami kesulitan dan kendala dalam membuat grafik yaitu menetapkan skala, menentukan letak titik koordinat, dan menghubungkan titik koordinat tersebut. Jadi, siswa belum begitu mampu membuat penyataan matematika secara tertulis maupun membuat grafik.

\section{Mengajukan Dugaan Melalui Pemilihan Rumus atau Defenisi}

Soal nomor 1B: Tentukan himpunan penyelesaian dari $\sin x=0$ untuk $0^{\circ} \leq$ $x \leq 2 \pi$, dengan menggunakan cara rumus persamaan trigonometri 


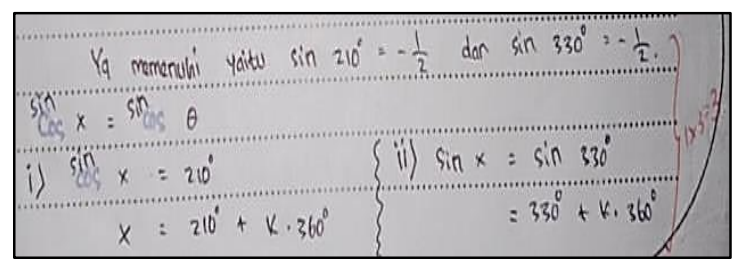

Gambar 6. Lembar Jawaban Siswa Kriteria Sangat Baik

Dari gambar tersebutsiswa berada pada skala 3. Berdasarkan hasil wawancara siswa mengatakan tidak mengalami kesulitan dikarenakan menurut siswa perintah soal dituliskan dengan jelas. Jadi, berdasarkan hasil lembar jawaban dan hasil wawancara diperoleh bahwa pada indikator mengajukan dugaan melalui pilihan rumus atau defenisi siswa mampu mengajukan dugaan dengan baik dan benar.

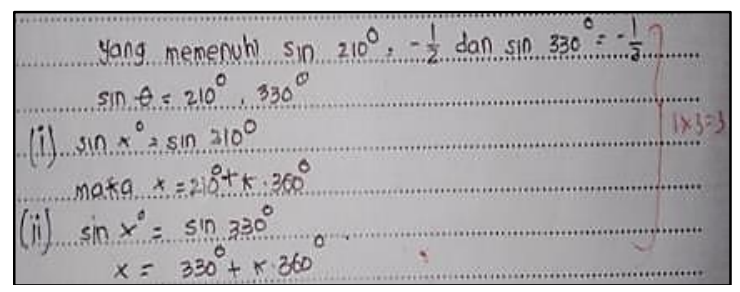

Gambar 7. Lembar Jawaban Siswa Kriteria Baik

Berdasarkan gambar tersebut bahwa siswa berada pada skala maksimal yaitu skala 3. Berdasarkan hasil wawancara siswa mengatakan sedikit kesulitan karena terkadang siswa ragu dan lupa rumus yang cocok untuk digunakan dalam menyelesaikan soal tersebut seperti pada rumus $\sin$, cos, dan tangen yang memiliki perbedaan. Jadi, terlihat dari hasil lembaran jawaban dan wawancara siswa diperoleh bahwa pada indikator mengajukan dugaan melalui pilihan rumus atau defenisi siswa mampu mengajukan dugaan dengan baik dan benar, walaupun siswa sedikit terkendala karena lupa atau ragu dengan rumus yang digunakan.

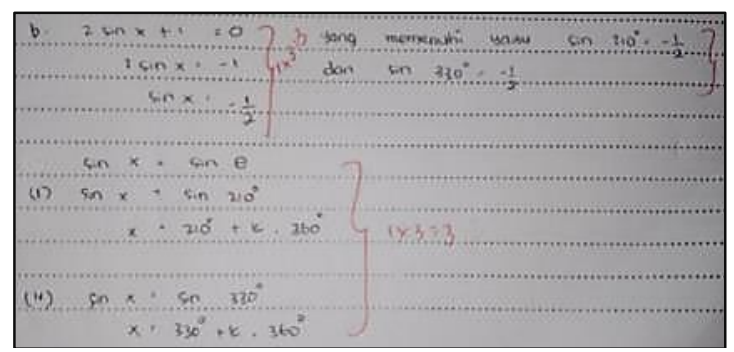

Gambar 8. Lembar Jawaban Siswa Kriteria Cukup Baik

Gambar diatas menunjukkkan bahwa siswa berada pada skala maksimal yaitu skala 3. Berdasarkan hasil wawancara siswa mengatakan tidak mengalami kendala dalam menentukan rumus yang digunakan dalam menyelesaikan soal. Jadi, dari hasil lembaran jawaban dan wawancara siswa diperoleh bahwa pada indikator mengajukan dugaan melalui pilihan rumus atau defenisi siswa mampu mengajukan dugaan dengan baik dan benar.

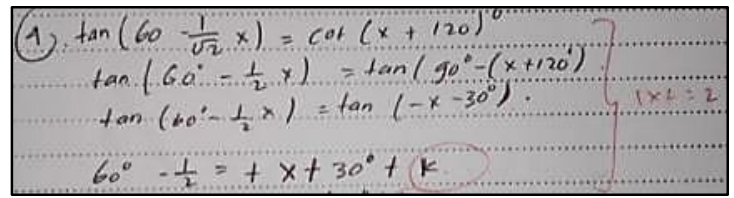

Gambar 9. Lembar Jawaban Siswa Kriteria Kurang Baik

Terlihat bahwa siswaberada pada skala 2, hal ini dikarenakan ada sedikit kekurangan dari jawaban siswa yaitu $60^{\circ}-$ $\frac{1}{2}=+x+30^{\circ}+k$, seharusnya jawaban yaitu $60^{\circ}-\frac{1}{2} x=-x-30^{\circ}+k$. $180^{\circ}$.Berdasarkan hasil wawancara siswa mengatakan tidak mengalami kendala dalam menentukan rumus yang cocok untuk digunakan dalam menyelesaikan soal. Jadi, berdasarkan hasil lembaran jawaban dan hasil wawancara siswa 
diperoleh bahwa pada indikator mengajukan dugaan melalui pilihan rumus atau defenisi siswa mampu mengajukan dugaan dengan baik dan benar dengan sedikit kekurangan dari jawaban yang diinginkan.

Pada lembar jawaban siswa kriteria Sangat Kurang, Siswa tidak menjawab soal maka berarti siswa tidak mampu mengajukan dugaan melalui pemilihan rumus atau defenisi. Berdasarkan hasil wawancara yang dilakukan, siswa tidak paham dengan materi.

\section{Melakukan Manipulasi Matematika Melalui Perhitungan}

Soal nomor 2: Tentukan himpunan penyelesaian persamaan $2 \cos ^{2} \theta+$ $3 \cos \theta+1=0$

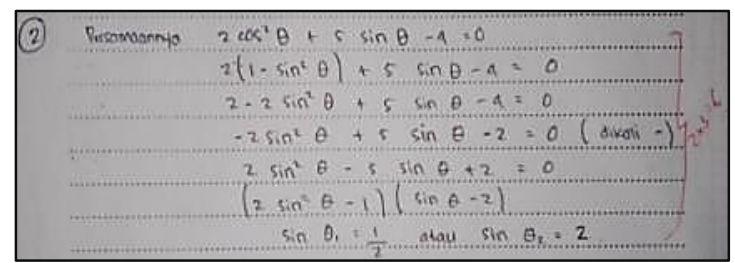

Gambar 10. Lembar Jawaban Siswa Kriteria Sangat Baik

Terlihat bahwa siswa berada pada skala 3. Berdasarkan hasil wawancara siswa mengatakan dapat melakukan manipulasi matematika untuk memudahkan suatu perhitungan dan memperoleh hasil dengan baik dan benar. Jadi, berdasarkan hasil lembaran jawaban dan hasil wawancara diperoleh bahwa siswa mampu melakukan manipulasi matematika melalui perhitungan dengan benar dan sempurna.

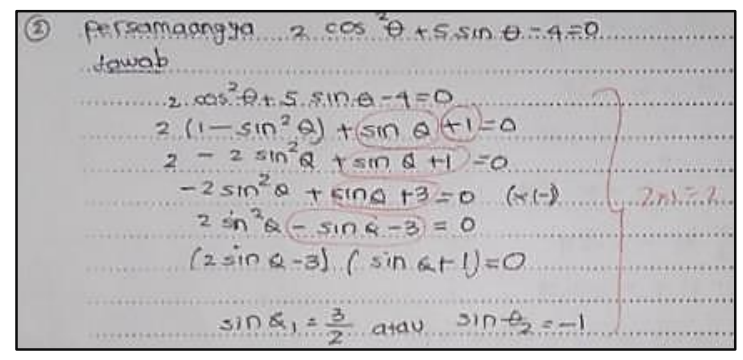

Gambar 11. Lembar Jawaban Siswa Baik

Dari gambar tersebut terlihat bahwa siswa berada pada skala 2, hal ini dikarenakan ada kekeliruan penjumlahan angka yaitu $5 \sin \theta-4$ ditulis $\sin \theta-$ 1.Berdasarkan hasil wawancara siswa mengatakan tidak mengalami kendala dalam melakukan perhitungan jika sudah mengetahui rumus yang cocok menyelesaikan soal. Jadi, berdasarkan hasil lembaran jawaban dan hasil wawancara diperoleh bahwa siswa mampu melakukan manipulasi matematika melalui perhitungan dengan benar dan sempurna.

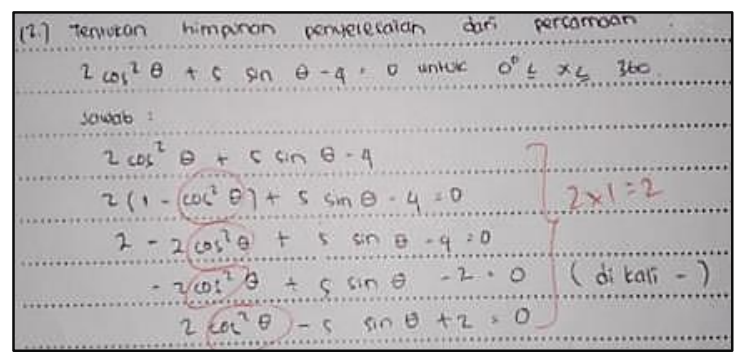

Gambar 12. Lembar Jawaban Siswa Kriteria Cukup Baik

Terlihat bahwa siswa berada pada skala 2, hal ini dikarenkan ada sedikit kesalahan yaitu pada perubahan bentuk $\cos ^{2} \theta$ menjadi bentuk identitas trigonometri yaitu $1-\cos ^{2} \theta$, yang seharusnya $\cos ^{2} \theta$ diubah menjadi $1-\sin ^{2} \theta$.Berdasarkan hasil wawancara siswa mengatakan dapat melakukan manipulasi matematika dalam perhitungan dan tidak mengalami kendala, akan tetapi 
pada lembar jawaban yang ditulis, siswa terlihat ada kekliruan dalam melakukan manipulasi. Jadi, berdasarkan hasil lembaran jawaban dan hasil wawancara diperoleh bahwa siswa mampu melakukan manipulasi matematika meskipun ada sedikit kesalahan dalam perhitungan.

Pada lembar jawaban siswa kriteria Kurang Baik, Siswa tidak menjawab soal. Berdasarkan hasil wawancara siswa mengatakanlupa akan caranya. Jadi, berdasarkan hasil lembaran jawaban dan hasil wawancara diperoleh bahwa siswa belum mampu melakukan manipulasi matematika dengan benar dan sempurna.

Pada lembar jawaban siswa kriteria Sangat Kurang, Siswa tidak menjawab soal. Berdasarkan hasil wawancara siswa mengatakan tidak dapat melakukan manipulasi matematika dalam perhitungan karena siswa tidak paham dengan materi. Jadi, berdasarkan hasil lembaran jawaban dan hasil wawancara diperoleh bahwa siswa belum mampu melakukan manipulasi matematika dengan benar dan sempurna.

\section{Menarik Kesimpulan dari Pernyataan Berikut ini adalah jawaban tes tertulis}

Soal nomor 1A: Tentukan himpunan penyelesaian dari $\sin x=0$ untuk $0^{\circ} \leq$ $x \leq 2 \pi$, dengan menggunakan cara grafik fungsi trigonometri.

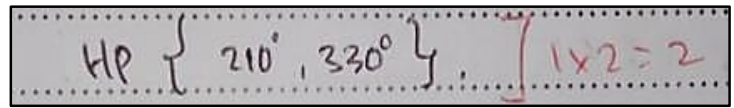

Gambar 13. Lembar Jawaban Siswa Kriteria Sangat Baik

Berdasarkan bahwa siswa berada pada skala maksimal yaitu skala 2, hal ini dikarenakan seharusnya dituliskan nilai $x$ yang memenuhi persamaan tersebut apa saja.Berdasarkan hasil wawancara siswa mengatakan dapat menarik kesimpulan dan tidak mengalami kesulitan.Jadi, berdasarkan hasil lembaran jawaban dan hasil wawancara diperoleh bahwa siswamampu menarik kesimpulan dengan jelas dan proses berfikir mudah dikuti.

Pada lembar jawaban siswa kriteria Baik, siswa tidak menarik kesimpulan dari apa yang didapatkan. Berdasarkan hasil wawancara siswa mengatakan sedikit mengalami kendala dalam menarik kesimpulan, yaitu pada saat siswa kurang yakin dengan jawabannya, dan jika siswa sudah tidak lagi menyelesaikan jawaban. Jadi, berdasarkan hasil jawaban siswa dan hasil wawancara diperoleh bahwa pada siswa belum mampu menarik kesimpulan dari penyataan dengan jelas.

Pada lembar jawaban siswa kriteria Cukup Baik, siswa tidak menarik kesimpulan dari apa yang didapatkan. Berdasarkan hasil wawancara siswa mengatakan tidak mengalami kesulitan namun pada lembar jawaban siswa terlihat bahwa siswa tidak menarik kesimpulan dari apa yang diperolehnya. Jadi, berdasarkan hasil jawaban siswa dan hasil wawancara diperoleh bahwa pada siswa belum mampu menarik kesimpulan dari penyataan dengan jelas.

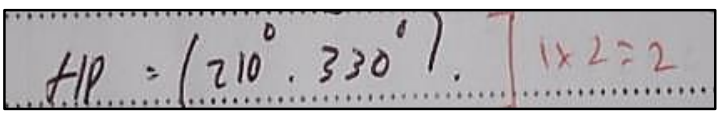

Gambar 14. Lembar Jawaban Siswa Kriteria Kurang Baik 
Dari gambar tersebut, bahwa siswa berada pada skala 2, karena seharusnya dituliskan nilai $x$ yang memenuhi persamaan tersebut apa saja. Berdasarkan hasil wawancara siswa mengatakan hanya menarik kesimpulan. Jadi, berdasarkan hasil jawaban siswa dan hasil wawancara bahwa siswa mampu menarik kesimpulan dari pernyataan dengan jelas dan benar.

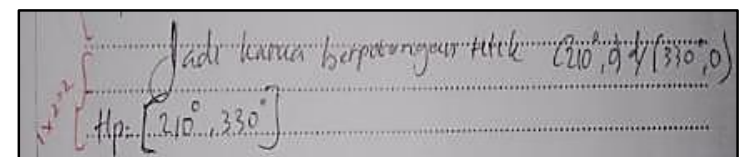

Gambar 15. Lembar Jawaban Siswa Kriteria Sangat Kurang

Terlihat bahwa siswa berada pada skala 2, karena seharusnya dituliskan nilai $x$ yang memenuhi persamaan tersebut apa saja. Berdasarkan hasil wawancara diperoleh siswa tidak mengerti dengan materi. Jadi, terlihat bahwa siswa belum mampu untuk manarik kesimpulan dari penyataan.

5. Menarik Kesimpulan, Menyusun Bukti, Memberikan Alasan atau Bukti Terhadap Beberapa Solusi

Soal nomor 3 : Untuk $0^{\circ} \leq x \leq 360^{\circ}$ tentukan penyelesaian dari $\cos (x-$ $\left.30^{\circ}\right)=\frac{1}{2} \sqrt{2}$

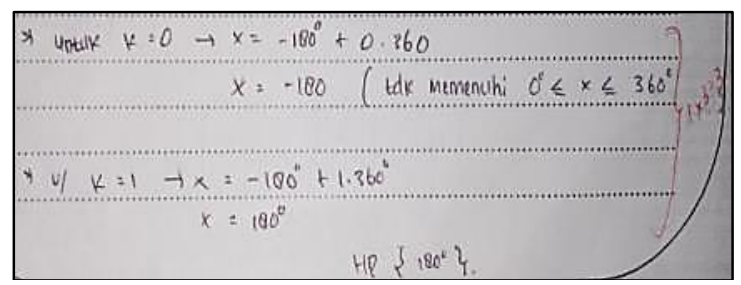

Gambar 15. Lembar Jawaban Siswa Kriteria Sangat Baik

Berdasarkan gambar, bahwa siswa berada pada skala 3. Berdasarkan hasil siswa mengatakan tidak mengalami kendala dalam menarik kesimpulan, menyusun bukti serta memberikan alasan karena siswa menganggap telah menyusun bukti, serta membuat kesimpulan dari jawaban. Jadi, berdasarkan hasil jawaban siswa dan hasil wawancara diperoleh bahwa siswa sudah mampu untuk menarik kesimpulan, menyusun bukti, memberikan alasan atau bukti, terhadap beberapa solusi dengan baik walaupun ada sedikit kekurangan.

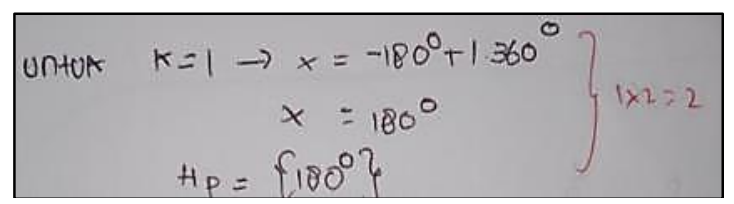

Gambar 16. Lembar Jawaban Siswa Kriteria Baik

Terlihat bahwa siswa berada pada skala2dikarenakan siswa sudah menarik kesimpulan namun tidak menyusun bukti. Berdasarkan hasil wawancara siswa mengatakan sedikit mengalami kendala dalam menarik kesimpulan, menyusun bukti, serta memberikan alasan, karena ada beberapa jawaban yang tidak disertai alasan. Jadi, berdasarkan hasil jawaban siswa dan hasil wawancara diperoleh bahwa siswa belum mampu untuk menarik kesimpulan, menyusun bukti, memberikan alasan atau bukti, terhadap beberapa solusi dengan baik dan benar.

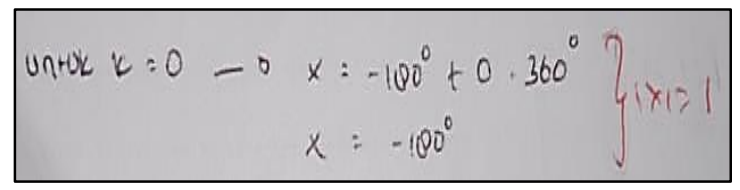

Gambar 18. Lembar Jawaban Siswa Kriteria Cukup Baik

Dari gambar diatas siswa berada pada skala1dikarenakan siswa tidak menarik kesimpulan serta tidak menyusun bukti. Berdasarkan hasil wawancara siswa 
mengatakan tidak mengalami kendala dalam menarik kesimpulan, menyusun bukti, memberikan alasan atau bukti terhadap beberapa solusi, akan tetapi pada lembar jawaban siswa terlihat bahwa siswa tidak menarik kesimpulan dan menyusun bukti dengan jelas. Jadi, berdasarkan hasil jawaban siswa dan hasil wawancara diperoleh bahwa siswa belum mampu untuk menarik kesimpulan, menyusun bukti, memberikan alasan atau bukti terhadap beberapa solusi dengan baik dan benar.

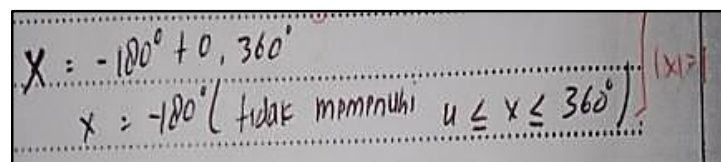

Gambar 19. Lembar Jawaban Siswa Kriteria Kurang Baik

Terlihat bahwa siswa berada pada skala 1, dikarenakan siswa tidak menarik kesimpulan serta tidak menyusun bukti. Berdasarkan hasil wawancara siswa mengatakan sedikit mengalami kendala dalam menarik kesimpulan, dan menyusun bukti, karena siswa ada yang tidak menyelesaikan jawaban sampai menemukan jawaban akhir. Jadi, berdasarkan hasil jawaban siswa dan hasil wawancara diperoleh bahwa siswa belum mampu untuk menarik kesimpulan, menyusun bukti, terhadap beberapa solusi dengan baik dan benar.

\section{Penutup}

Berlandaskan hasil penelitian dan pembahasan dari keseluruhan, dapat disimpulkan bahwa kemampuan penalaran dan komunikasi siswa kelas XI MIA SMAN 1
Koto Salak dominan berada pada kriteria kurang baik, dan berdasarkan indikator kemampuan penalaran dan komunikasi matematis, siswa hanya memiliki ketercapaian maksimal pada indikator mengajukan dugaan melalui pemilihan rumus atau definisi, dan indikator melakukan manipulasi matematika melalui perhitungan.

\section{Daftar Pustaka}

Afriansyah, E. A. (2013). Design Research: Mengukur Kepadatan Bilangan Desimal. Seminar Nasional Matematika dan Pendidikan Matematika STKIP Siliwangi 1.

Agisti, N. S. (2009). Implementasi Strategi Means-End Analysis untuk Meningkatkan Kemampuan Siswa SMP dalam Komunikasi Matematis. Skripsi pada FPMIPA Universitas Pendidikan Indonesia. Bandung: Tidak diterbitkan.

Arikunto, S. (2008). Dasar-Dasar Evaluasi Pendidikan. Jakarta: Bumi Aksara.

Asmara, R., \& Afriansyah, E. A. (2018). Perbedaan Peningkatan Kemampuan Komunikasi Matematis Siswa antara Model Eliciting Activities dan Discovery Learning. Suska Journal of Mathematics Education, 4(2), 78-87.

Dewi S. S. S., \& Afriansyah, E. A. (2018). Kemampuan Komunikasi Matematis Siswa Melalui Pembelajaran CTL. JIPMat, 3(2). 
Emilya, D. (n.d.). (2010). Matematika Siswa Kelas VIII Sekolah Menengah Pertama Negeri 10 Palembang.

Inayah, N. (2016). Pengaruh kemampuan penalaran matematis dan gaya kognitif terhadap kemampuan komunikasi dan koneksi pada materi statistika siswa SMA. Jurnal EST, 2(5), 74-80.

Khoirudin, \& Rizkianto, I. (2018). Pengembangan perangkat pembelajaran problem based learning dan learning trajectory yang berorientasi pada kemampuan penalaran matematis siswa. Mosharafa: Jurnal Pendidikan Matematika, 7(2), 207-218.

Luritawaty, I. P. (2019). Pengembangan Kemampuan Komunikasi Matematik melalui Pembelajaran Take and Give. Mosharafa: Jurnal Pendidikan Matematika, 8(2), 239-248.

Shadiq, F. (2009). Kemahiran Matematika. Yogyakarta: Depdiknas.

Rosita, C. D. (2008). Kemampuan Penalaran dan Komunikasi Matematis: Apa, Mengapa, dan Bagaimana Ditingkatkan pada Mahasiswa. Jurnal Euclid, 1(1), 33-46. Soedjadi, R. (2000). Kiat Pendidikan Matematika di Indonesia. Jakarta: Direktorat Jenderal Pendidikan Tinggi Departemen Pendidikan Nasional.

Utomo, E. S., Rahman, F., \& Fikrati, A. N. (2020). Eksplorasi Penalaran Logis Calon Guru Matematika Melalui Pengintegrasian Pendekatan STEM dalam Menyelesaikan Soal. Mosharafa: Jurnal Pendidikan Matematika, 9(1), 13-22.

\section{Riwayat Hidup PENUlis Dra. Sefna Rismen, M.Pd.}

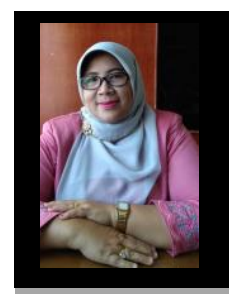

Lahir di Sei. Rimbang, Kec Suliki Gunung Mas, Kab. 50 Kota, pada tanggal 10 September 1965. Bekerja sebagai dosen tetap pnsd di STKIP PGRI Sumatera Barat. Studi S1 di FKP Universitas September 1965. Bekerja sebagai dosen tetap pnsd di STKIP PGRI Sumatera Barat. Studi S1 di FKP Universitas Bung Hatta, Padang, lulus tahun 1990; dan S2 jurusan Administrasi Pendidikan di Universitas Negeri Padang (UNP), Padang, lulus tahun 2000.

\section{Ainil Mardiyah, M.Si.}

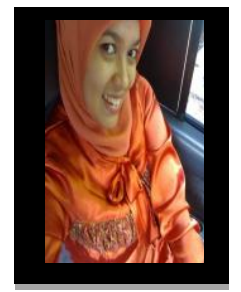
Lahir di Dusun Baru Sungai Penuh, pada tanggal 03 Januari 1987. Bekerja sebagai dosen tetap di STKIP PGRI Sumatera Barat. Studi S1 Matematika FMIPA Unand, Padang, lulus tahun 2008. Studi S2 Matematika Unand, Padang, lulus tahun 2011.

\section{Ega Meilia Puspita, S.Pd.}

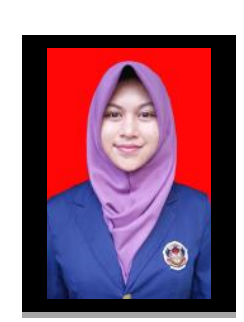

Lahir di Ampalu, Kec. Koto Salak, Kab. Dharmasraya, pada tanggal o9 Mei 1997. Studi S1Pendidikan Matematika di STKIP PGRI Sumatera Barat, Padang, lulus tahun 2019. 